\title{
PERLINDUNGAN HUKUM BAGI NASABAH PERUSAHAAN PEGADAIAN
}

Oleh:

\author{
Ana Suheri \\ Fakultas Hukum Universitas PGRI Palangka Raya
}

\begin{abstract}
Abstrak :
Di dalam melaksanakan suatu perjanjian gadai perlu diketahui pihak-pihak yang terkait dalam suatu perjajian tersebut seperti pihak pertama (perusahaan umum pegadaian) dan pihak kedua (nasabah atau perseorangan) yang mana Pihak Pertama atau perusahaan umum pegadaian adalah pihak pemberi gadai atau pemberi pinjaman terhadap nasabah yang menggadaikan kepadanya sedangkan Pihak Kedua atau nasabah adalah pihak yang memiliki utang atau angsuran gadai terhadap pihak pertama atau perusahaan umum pegadaian. Metode yang digunakan dalam penelitian ini adalah metode yuridis normatif. Tujuan dari penelitian ini adalah mengetahui kedudukan hukum antara kedua belah pihak dalam Perusahaan Umum Pegadaian, dan untuk mengetahui perlindungan hukum bagi nasabah Perusahaan Umum Pegadaian apabila barang jaminan rusak/hilang. Penelitian ini mengetahui bahwa perusahaan pegadaian memberikan pergantian kerugian sebesar $125 \%$ dari nilai taksiran barang jaminan yang mengalami kerusakan/hilang yang disebabkan bukan karena Force Majeure (keadaan memaksa) dan membuat asuransi atas atas barang jaminan tersebut untuk mendapatkan kepastian hukum bagi nasabah Perusahaan Umum Pegadaian
\end{abstract}

Kata Kunci : Perlindungan Hukum, Pegadaian, Nasabah.

\section{Abstract:}

In implementing a pawn agreement, it is necessary to know the parties involved in an agreement such as the first party (public pawnshop company) and the second party (customer or individual) where the First Party or public pawnshop company is the party that gives the pawn or lender to the customer. who pawned him. In contrast, the Second Party or the customer is the party who has debts or mortgage installments against the first party or public pawnshop company. Which is used in this research is the normative juridical method. The purpose of this study is to determine the legal position between the two parties in the Public Pawnshop and to find out legal protection for customers of the Public Company Pegadaian if the collateral is damaged/lost. This study finds out that the pawnshop company provides compensation for losses of $125 \%$ of the estimated value of collateral damaged/lost due not to Force Majeure and makes insurance on the collateral to obtain legal certainty for customers of the Public Pawnshop.

Keywords: Legal Protection, Pawnshops, Customers.

PENDAHULUAN

Sebagai pemberdayaan ekonomi rakyat sekarang ini, banyak bermunculan perusahaan atau lembaga-lembaga yang menitik beratkan pada pemberian kredit atau pinjaman modal dengan menggadaikan barang kepunyaan masyarakat sebagai jaminan atas pinjaman kredit atau modal usaha mereka. Dimana kegiatan usaha perusahaan atau lembaga 
tersebut menyediakan dana yang dibutuhkan oleh masyarakat ekonomi lemah yang ingin memiliki pinjaman modal usaha atau memerlukan pinjaman uang untuk kebutuhan yang tidak terduga sebelumnya secara cepat dan mudah.

Dengan adanya bidang usaha ini masyarakat ekonomi lemah merasa sangat terbantu untuk dapat memiliki pinjaman modal atau pinjaman uang secara mudah, cepat, dan tidak memerlukan birokrasi yang lama dengan bunga yang relatif rendah. Agar keinginan mereka tersebut dapat tercapai maka jalan satu-satunya sebagai tumpuan masyarakat adalah melalui Perusahaan Umum Pegadaian dimana bagi masyarakat ekonomi lemah yang menginginkan pinjaman modal atau pinjaman uang secara mudah, cepat, dan tidak memerlukan birokrasi yang lama dapat menyerahkan barang kepada juru taksir Perusahaan Umum Pegadaian.

Pada dasarnya, prosedur dalam peminjaman dan pelunasan kredit gadai sangat praktis, karena tidak memerlukan birokrasi yang panjang, karena didalam peminjaman dan pengembalian kredit tidak melibatkan instansi yang lainnya (Fahlevhy, 2016). Peminjaman kredit dengan konstruksi gadai ini hanya melibatkan lembaga pegadaian sematamata dan kontruksi gadai tidak memerlukan birokrasi yang panjang dan biaya kecil, bahkan dianggap tidak ada biaya.

Jadi disini, masyarakat yang menginginkan pinjaman modal usaha atau pinjaman uang merasa sangat terbantu oleh Perusahaan Umum Pegadaian. Dimana mereka tidak harus lagi meminjam uang di lembaga perbankan yang memerlukan biaya yang sangat besar, waktu yang lama, birokrasi yang panjang dan harus melakukan koordinasi dengan berbagai instansi lainnya seperti Notaris, Kantor Badan Pertanahan, Kantor Wilayah Departemen Kehakiman dan HAM, dan berbagai instansi lainnya.

Karena pinjaman modal usaha dan pinjaman uang tersebut dengan cara menggadaikan barang mereka, maka barang tersebut di jaminkan oleh Perusahaan Umum Pegadaian untuk pelunasan suatu hutang gadai. Dari sini timbul hubungan hukum antara Perusahaan Umum Pegadaian dengan Nasabah/masyarakat yang mempunyai barang yang digadaikan.

Hubungan tersebut timbul karena kedua belah pihak yaitu Perusahaan Umum Pegadaian dan Nasabah Perusahaan Umum Pegadaian mengadakan perjanjian yang pokoknya adalah perjanjian pinjammeminjam uang dengan jaminan benda 
bergerak atas pelunasan hutang gadai, ketika nasabah lalai dalam melaksanakan prestasinya. Ketentuan tentang bentuk perjanjian gadai dapat dilihat dalam Pasal 1151 Kitab Undang-Undang Hukum Perdata yang berbunyi, "Persetujuan gadai dibuktikan dengan segala alat yang diperbolehkan bagi pembuktian persetujuannya pokok".

Pengertian tentang gadai juga tercantum dalam Kitab Undang-Undang Hukum Perdata Pasal 1150 yang berbunyi

Gadai adalah hak yang diperoleh seorang berpiutang atas suatu barang bergerak, yang diserahkan kepadanya oleh seorang berutang atau oleh seorang lain atas namanya, dan yang memberikan kekuasaan kepada si berpiutang itu untuk mengambil pelunasan dari barang tersebut secara didahulukan dari pada orang-orang yang berpiutang lainnya ; dengan kekecualian biaya untuk melelang barang tersebut dan biaya yang telah dikeluarkan untuk menyelamatkannya setelah barang itu digadaikan, biaya-biaya mana harus didahulukan.

Munculnya Perusahaan Umum Pegadaian ini merupakan suatu alternatif yang menarik bagi masyarakat karena saat ini memang sulit didapat dana rupiah untuk jangka waktu menengah dan panjang. Sedangkan melalui Perusahaan Umum Pegadaian masyarakat ekonomi kebawah bisa memperoleh pinjaman modal atau pinjaman uang dengan jangka waktu yang lama sesuai dengan nilai taksir dari juru taksir Perusahaan Umum Pegadaian (Puspita \& Djaroem, 2004).

Bila kita lihat dalam melakukan gadai melalui Perusahaan Umum Pegadaian sangatlah mungkin terjadi apabila barang yang digadaikan oleh nasabah Perusahaan Umum Pegadaian terdapat cacat, rusak atau musnah akibat kelalaian Perusahaan Umum Pegadaian.

Berdasarkan hasil penelitian oleh Trisadini Prasastinah Usanti, menyatakan bahwa dalam kemudahan yang diberikan oleh perusahaan pergadaian perlu diberikan kepastian hukum melalui Peraturan OJK 2016 yang mengatur perlindungan hukum baik preventif maupun represif (Usanti, 2019).

Selain itu menurut penelitian oleh Rizki Sukma Hapsari, upaya hukum sebagai bentuk perlindungan hukum kepada nasabah yang mengalami wanprestasi oleh perusahaan pergadaian dapat melalui musyawarah mufakat, mediasi dan peradilan (Hapsari, 2016). 
Metodologi Penelitian yang digunakan dalam penelitian ini adalah metode yuridis normatif yakni dengan mempelajari dan mengkaji asas-asas hukum khususnya kaidah-kaidah hukum positif dalam peraturan perundangundangan, bahan-bahan hukum yang penulis dapatkan dari studi kepustakaan sebagai dasar telaah terhadap permasalahan yang telah dirumuskan dalam penelitian ini (Rahayu et al., 2020).

Tujuan Penelitian ini adalah Untuk mengetahui kedudukan hukum antara kedua belah pihak dalam Perusahaan Umum Pegadaian, dan untuk mengetahui perlindungan hukum bagi nasabah Perusahaan Umum Pegadaian apabila barang jaminan rusak/hilang.

\section{PEMBAHASAN}

\section{Kedudukan Hukum Antara Kedua}

Belah Pihak Terhadap Barang Jaminan

Dalam Perusahaan Umum Pegadaian.

Di dalam melaksanakan suatu perjajian gadai perlu diketahui pihak-pihak yang terkait dalam suatu perjajian tersebut seperti pihak pertama (perusahaan umum pegadaian) dan pihak kedua (nasabah atau perseorangan) yang mana Pihak Pertama atau perusahaan umum pegaaian adalah pihak pemberi gadai atau pemberi pinjaman terhadap nasabah yang menggadaikan kepadanya sedangkan Pihak
Kedua atau nasabah adalah pihak yang memiliki utang atau angsuran gadai terhadap pihak pertama atau perusahaan umum pegadaian.

\section{Pihak-Pihak Dalam Perjanjian}

\section{Gadai.}

Dalam melakukan perjanjian

Gadai pada Perusahaan Umum Pegadaian, maka terlebih dahulu kita harus mengetahu para pihak dalam perjanjian gadai tersebut. Para pihak tersebut antara lain :

\section{a. Penerima Gadai atau}

\section{Perusahaan Umum Pegadaian}

Penerima gadai bisa juga disebut dengan kreditur. Tentang pengertian Kreditur disni adalah Perusahaan Umum Pegadaian dimana dalam suatu kegiatannya menyediakan uang atau tagihantagihan yang dapat disamakan dengan itu berdasarkan persetujuan pinjam-meminjam atau persetujuan gadai antara pihak kreditur dan pihak debitur dimana pihak pemberi gadai berkewajiban melunasi utang gadainya setelah jangka waktu tertentu dengan jumlah bunga yang telah ditetapkan. Dengan kata lain kreditur adalah pihak yang memiliki tagihan atau hak tagih 
berupa pembayaran sejumlah uang dari debitur yang timbul karena perjanjian antara kedua belah pihak (Hasibuan, 2017). Kewajiban Kreditur atau Penerima Gadai adalah :

1. Pemegang gadai bertanggung jawab atas hilangnya atau merosotnya harga benda yang digadaikan, apabila semua itu terjadi atas kelalaian (Pasal 1157 ayat (1) Kitab UndangUndang Hukum Acara Perdata). Pasal 1157 ayat (1) Kitab Undang-Undang Hukum Perdata berbunyi:

Sebaliknya si berutang adalah bertanggung-jawab diwajibkan mengganti kepada si berpiutang segala biaya yang berguna dan perlu, yang telah dikeluarkan oleh pihak yang tersebut belakang ini guna keselamata barangnya gadai.

2. Pemegang gadai tidak diperbolehkan untuk menggunakan barang barang gadai untuk keperluan sendiri. Jika si-pemegang gadai menyalah gunakan barang tersebut maka barang itu dapat diminta kembali oleh pemberi gadai.

Perjanjian gadai merupakan perjanjian accesoir yakni perjanjian selalu bersandar pada perjanjian pokok yang berupa perjanjian pinjam-meminjam uang (Herawaty, 2008). Oleh karena itu apabila utang yang dijamin dengan gadai sudah lunas, maka hak gadai itu hapus apabila barang gadai keluar dari kekuasaan si pemegang gadai atau perusahaan umum pegadaian.

Dari pengertian diatas maka dapat kita simpulkan bahwa kreditur atau Perusahaan Umum Pegadaian adalah penyedia uang untuk dipinjamkan kepada debitur dengan menggadaikan sesuatu barang kepada kreditur atau Perusahaan Umum Pegadaian kemudian debitur atau nasabah Perusahaan Umum Pegadaian pembayaran secara berkala sesuai dengan perjajian antara kedua belah pihak (debitur dan kreditur). 
Dalam prakteknya, kreditur atau Perusahaan Umum Pegadaian memberikan kredit kepada Nasabah dengan jaminan barang bergerak yang nilai taksirnya disepakati. Seperti yang tercantum dalam Pasal 1 Perjanjian Kredit Dengan Jaminan Barang Bergerak pada Perusahaan Umum Pegadaian yang berbunyi:

Pegadaian memberikan kredit kepada Nasabah atau yang dikuasakan dengan jaminan barang bergerak yang nilai taksirnya disepakati sebesar sebagaimana yang tercantum dalam halaman depan.

Dasar hukum gadai atau peraturan tentang gadai yang masih berlaku sampai sekarang ini adalah

1. Pasal 1150 Kitab UndangUndang Hukum Perdata sampai dengan Pasal 1160 Kitab Undang-Undang Hukum Perdata;

2. Peraturan Pemerintah Nomor 103 Tahun 2000 tentang
Perusahaan Umum (perum)

Pegadaian.

Di Indonesia lembaga yang ditunjuk untuk menerima dan menyalurkan kredit berdasarkan hukum gadai adalah Lembaga Pegadaian.

Perusahaan Jawatan (PERJAN) Pegadaian yang didirikan berdasarkan Peraturan Pemerintah No.7 Tahun 1969, dialihkan bentuknya menjadi Perusahaan Umum (PERUM) sebagaimana dimaksud dalam Pasal 2 ayat (2) Undang-Undang No.9 Tahun 1969, dengan nama Perusahaan Umum (PERUM) Pegadaian dan meneruskan usahausaha selanjutnya berdasarkan ketentuan-ketentuan dalam Peraturan Pemerintah.

Selanjutnya dengan dialihkannya bentuk Perusahaan Jawatan (PERJAN) Pegadaian menjadi Perusahaan Umum (PERUM), Perusahaan Jawatan (PERJAN) Pegadaian dinyatakan bubar pada saat pendirian Perusahaan Umum (PERUM) tersebut dengan ketentuan segala hak dan kewajiban, kekayaan dan termasuk seluruh pegawai 
Perusahaan Jawatan (PERJAN)

Pegadaian yang ada pada saat pembubarannya beralih kepada Perusahaan Umum (PERUM) yang bersangkutan.

\begin{tabular}{|c|c|c|}
\hline & Peraturan & Pemerintah \\
\hline No. 10 & Tahun & tentang \\
\hline
\end{tabular}

Pengalihan Bentuk Perusahaan Jawatan (PERJAN) Pegadaian Menjadi Perusahaan Umum Pegadaian :

Pasal 3 ayat (1) dan (2) yang berbunyi :

(1) Perusahaan sebagaiman dimaksudkan dalam pasal 2 adalah badan usaha tunggal yang diberi wewenang untuk menyalur uang pinjaman atas dasar hukum gadai.

(2) Perusahaan melakukan usahausahanya berdasarkan ketentuan dalam peraturan pemerintah ini dan peraturan perudang-undangan yang berlaku.

Pasal 5 ayat (1) dan (2) yang berbunyi :

(1) Sifat usaha dari perusahaan dalam menyediakan pelayanan bagi pemamfaatan umum dan sekaligus memupuk keuntungan berdasarkan prisnsip pengelolaan

perusahaan.

(2) Perusahaan bertujuan :

a. turut melaksanakan dan menunjang pelaksanaan kebijakan dan program pemerintah dibidang ekonomi dan pembangunan nasional pada umumnya melalui penyaluran uang pinjaman atas dasar hukum gadai;

b. pencegahan praktek pegadaian gelap, riba, dan pinajaman tidak wajar lainnya;

Pasal 9 yang berbunyi :

Perusahan dapat memperoleh dan menggunakan dana yang diperoleh untuk mengembangkan usahanya melalui pengeluaran obligasi atau alat-alat yang sah lainnya, pengeluaran obligasi atau alat-alat yang sah lainnya sebagaimana yang dimaksud dalam ayat (1) termasuk ketentuan-ketentuan yang berhubungan dengan itu, diatur dengan peratudan pemerintah.

Pasal 19 ayat (1 sampai 5) yang berbunyi :

(1) Selambat-lambatnya 3 bulan sebelum tahun buku mulai 
berlaku, direksi mengirimkan rencana kerja dan anggaran perusahaan yang meliputi anggaran investasi dan anggaran eksploitasi kepada menteri untuk memperoleh pengesahannya.

(2) Kecuali apabila menteri secara tertulis mengemukakan keberatan atau menolak kegiatan yang dimuat dalam rencana kerja dan anggaran perusahaan sebelum menginjak tahun buku baru, maka anggaran tersebut berlaku sepenuhnya.

(3) Rencana kerja dan atau anggaran tambahan atau perubahan yang tertera didalam tahun buku yang bersangkutan harus diajukan terlebih dahulu kepada menteri untuk memperoleh pengesahannya, menurut cara dan waktu yang ditetapkan oleh menteri.

(4) Apabila dalam waktu 3 bulan sesudah permintaan persetujuan sebagaimana dimaksud dalam ayat (3) diajukan, oleh menteri tidak diberikan keberatan secara tertulis, maka perubahan rencana kerja dan anggaran tersebut telah disahkan.

(5) Rencana kerja dan atau anggaran perusahaan yang telah disahkan merupakan landasan kerja dan menjadi tugas bagi direksi untuk melaksanakan kegiatan yang kerja dan menjadi tugas bagi direksi untuk melaksankan kegiatan yang tercantum didalamnya.

\section{b. Pemberi Gadai atau Nasabah}

Perusahaan

Umum

\section{Pegadaian.}

Didalam prakteknya, nasabah menyerahkan barang sebagai jaminan kredit kepada pegadaian, dengan menjamin bahwa barang jaminan tersebut adalah benar-benar hak miliknya, tidak ada pihak lain yang turut memiliki atau menguasainya. Seperti yang tercantum dalam Pasal 2 Perjanjian Kredit Dengan Jaminan Barang Bergerak pada Perusahaan Umum Pegadaian yang berbunyi :

$$
\begin{aligned}
& \text { Nasabah atau yang } \\
& \text { dikuasakan menyerahkan } \\
& \text { barang sebagai jaminan }
\end{aligned}
$$


kredit kepada Pegadaian, sebagaimana uraian yang tertera pada halaman depan, dengan menjamin bahwa barang jaminan tersebut adalah benarbenar hak miliknya secara penuh, tidak ada pihak lain yang turut memiliki atau menguasaianya.

Nasabah Perusahaan

Umum Pegadaian dapat juga disebut dengan Debitur karena pada dasarnya perjanjian gadai ini sama dengan pinjammeminjam, yang membedakannya adalah perjanjian gadai hanya dapat dilakukan dengan menggadaikan sesuatu untuk menerima pinjaman kredit sebagai jaminan atas lunasnya pinjaman kredit itu..

Mengenai pengertian debitur disini ialah pihak yang memiliki tanggungan terhadap pinjaman kredit yang diberikan kreditur kepadanya. Menurut Pasal 1235 Kitab UndangUndang Hukum Perdata yang berbunyi:
Dalam tiap-tiap perikatan untuk memberikan sesuatu adalah termaktub kewajiban siberutang untuk menyerahkan kebendaan yang bersangkutan dan untuk merawatnya sampai pada saat penyerahan.

Kemudian dikaitkan dengan ketentuan pada Pasal 1234 Kitab Undang-Undang Hukum Perdata yang berbunyi, "Tiap-tiap perikatan adalah untuk memberi sesuatu, untuk berbuat sesuatu, atau untuk tidak berbuat sesuatu" dan Pasal 1239 Kitab UndangUndang Hukum Perdata yang berbunyi :

Tiap-tiap perikatan untuk berbuat sesuatu, atau untuk tidak berbuat sesuatu, apabila siberutang tidak memenuhi kewajibannya, mendapatkan penyelesaiannya memberikan penggantian biaya, rugi dan bunga.

Debitur adalah pihak yang wajib memberikan 
sesuatu, berbuat sesuatu atau

tidak berbuat sesuatu

berkenaan dengan

perikatannya, baik timbul

karena perjanjian maupun

Undang-Undang seperti

tercantum dalam Pasal 1233

Kitab Undang-Undang Hukum

Perdata.

Kewajiban debitur adalah mengembalikan pinjaman kredit dalam jumlah yang sudah ditentukan, kewajiban ini diatur dalam Pasal 1763 Kitab Undang-Undang Hukum Perdata yang berbunyi, "Siapa yang menerima pinjaman sesuatu diwajibkan mengembalikannya dalam jumlah dan keadaan yang sama, dan pada waktu yang ditentukan" dan 1764 Kitab Undang-Undang Hukum Perdata yang berbunyi :

Jika tidak ia tidak mampu memenuhi kewajiban ini, maka ia diwajibkan membayar harganya barang yang dipinjamnya, dalam hal mana harus diperhatikan waktu dan tempat dimana barangnya, menurut persetujuan, sedianya harus dikembalikan.

Jika waktu dan tenpat ini tidak telah ditentukan, pelunasannya harus dilakukan menurut harga barang pinjaman pada waktu dan ditempat dimana pinjaman telah terjadi.

Jika dalam jangka waktu yang telah ditentukan nasabah atau debitur tidak mampu memenuhi kewajibannya, maka kreditur atau Perusahaan Umum Pegadaian memberikan somasi kepada pemberi gadai atau debitur sesuai dengan yang diperjanjiakan. Apabila somasi tersebut telah dilakukan selama 3 kali dan tidak ada jawaban dari pemberi gadai atau debitur, maka Perusahaan Umum Pegadaian atau kreditur dapat melakukan pelelangan terhadap benda gadai seperti tercantum dalam Pasal 1156 Kitab Undang-Undang Hukum Perdata.

Setelah penulis menguraikan tentang pihak-pihak 
dalam perjanjian gadai tersebut, dapat disimpulkan bahwa ada dua hal yang penting yang menjamin kedudukan kreditur atau Persahaan Pegadaian yang aman yaitu :

1. Hak mendahulu yang artinya penerima gadai mempunyai hak atas barang gadai tersebut.

2. Hak kebendaan atas barang yang artinya dapat disimpulkan pada Pasal 1152 ayat (3) Kitab Undang-Undang Hukum Perdata yang berbunyi :

Hak gadai hapus, apabila barangnya gadai keluar dari kekuasaan si penerima gadai. Apabila, namun itu barang tersebut hilang dari tangannya penerma gadai ini atau dicuri dari padanya, maka berhaklah ia menuntut kembali sebagaimana disebutkan dalam pasal 1977 ayat (2), sedangkan apabila barangnya gadai didapatnya kembali, hak gadai dianggap tidak pernah hilang.

\author{
Pasal 1977 ayat (2) Kitab \\ Undang-Undang \\ Hukum \\ Perdata yang berbunyi :
}

Namun demikian, siapa yang kehilangan atau kecurian sesuatu barang, didalam jangka waktu tiga tahun, terhitung sejak hari hilangnya atau dicurinya barang itu, dapatlah ia menuntut kembali barangnya yang hilang atau dicuri itu sebagai miliknya. Dari siapa yang dalam tangannya ia ketemukan barangnya, dengan tak mengurangi hak si yang tersebut belakangan ini untuk minta ganti rugi kepada orang dari siapa ia memperoleh barangnya, lagi pula dengan tak mengurangi ketentuan dalam pasal 582.

Pasal 582 Kitab UndangUndang Hukum Perdata yang berbunyi:

Barang siapa menuntut kembaliannya suatu kebendaan 
yang telah dicuri atau dihilangkan, tak diwajibkan memberi pergantian kepada si yang memegangnya, untuk uang yang telah dibayarkannya guna membelinya, kecuali kebendaan itu dibelinya di pasar tahunan atau pasar lainnya, dilelangan umum, atau dari seorang pedagang yang terkenal sebagai seorang yang biasanya memperdagangkan barang-barang sejenis itu.

Setiap nasabah atau
pemberi gadai yang ingin mendapatkan pinjaman uang dari Lembaga Pegadaian, nasabah tersebut harus menyampaikan keinginan kepada penerima gadai dengan menyerahkan obyek gadai kepada penaksir gadai pada Perusahaan Umum Pegadaian (AFIF et al., 2018).

\section{Prosedur Pengajuan :}

a. Datang ke kantor cabang Pegadaian setempat;

b. Membawa ASLI foto copy KTP, Kartu Keluarga;

c. Mengisi Formulir Permintaan Kredit yang telah disediakan; d. Menunjukan asli dan menyerahkan foto copy BPKB kendaraan bermotor yang akan di jaminkan;

e. Menunjukan Kendaraan yang akan di jadikan jaminan;

f. Menandatangai Surat Bukti Kredit;

\section{Prosedur Pencairan Dana :}

a. Setelah di survey, ada pemberitahuan permohonan kredit diterima;

b. Menyerahkan asli BPKB (Bukti Pemilik Kedaraan Bermotor) yang telah menjadi jaminan;

c. Menanda tangani Perjanjian Kredit dan Perikatan Fidusia;

d. Menerima Uang Pinjaman.

Sesuai dengan motto dari Pegadaian yaitu "mengatasi masalah tanpa masalah", pegadaian berusaha menawarkan sejumlah fasilitas-fasilitas pinjaman agar para nasabah Perusahaan Umum Pegadaian tidak berpaling dari Lembaga tersebut.

Kian banyaknya nasabah Perusahaan Umum Pegadaian untuk menggadaikan barang-barangnya itu tidak menutup kemungkinan barang yang di 
gadaikan tersebut rusak atau hilang. Nasabah yang merasa barangnya tersebut rusak atau hilang pada saat pengambilan atau pemberitahuan dari Perusahaan Umum Pegadaian bisa menuntut apabila barangnya tersebut tidak kembali seperti semula atau bagi yang kehilangan otomatis meminta ganti kerugian berupa barang yang sama.

Kitab Undang-Undang Hukum Perdata Pasal 1157 ayat (1) menerangkan tentang tanggung jawab penerima gadai atau Perusahaan Umum Pegadaian apabila barang gadai tersebut rusak atau hilang. Pasal 1157 ayat (1) tersebut berbunyi, "Siberpiutang adalah bertanggung jawab untuk hilangnya atau kemerosotannya barangnya sekedar itu telah terjadi karena kelalainnya".

Kemudian pada Surat Bukti Kredit dari Pegadaian tercantum poin yang menyebutkan bahwa apabila terjadi permasalahan dikemudian hari akan diselesaikan secara musyawarah untuk mufakat. Jika ternyata perselisihan itu tidak dapat diselesaikan secara musyawarah untuk mufakat, maka akan diselesiakan melalui pengadilan negeri setempat. Hal tersebut mungkin dapat meringankan beban dari nasabah Perusahaan Umum Pegadaian untuk tidak sesegera mungkin menuntut pergantian barang gadai apabila barang gadai tersebut rusak atau hilang.

Point selanjutnya pada Surat Bukti Kredit Perusahaan Umum Pegadaian Palangkaraya juga memuat tanggung jawab pihak Pegadaian untuk bertanggung jawab apabila barang tersebut rusak atau hilang yang bunyi dari point tersebut yang berbunyi :

Apabila dikemudian hari barang jaminan mengalami kerusakan atau hilang yang disebabkan bukan karena force majeure yang antara lain namun tidak terbatas karena, bencana lam, perang, huru-hara maka akan diberikan pergantian kerugian sebesar $125 \%$ dari nilai taksir barang jaminan yang mengalami kerusakan/hilang, atau sesuai dengan ketentuan yang berlaku dari pihak pegadaian, dan pembayaran akan diperhitungkan dengan kewajiban nasabah untuk melunasi uang pinjaman dan sewa modal yang ditentukan.

Jadi disini perlindungan hukum bagi nasabah Perusahaan Umum Pegadaian hanya pada Pasal 1157 ayat (1) Kitab Undang-Undang Hukum Perdata yang menerangkan si-berpiutang bertanggung jawab untuk hilangnya atau kemerosotannya barang gadai nasabah 
karena kelalainnya. Hal ini dikarenakan Perusahaan Umum Pegadaian melalui Surat Bukti Kreditnya mencantumkan Point bahwa Pegadaian memperhitungkan lagi biaya pinjaman dari nasabah beserta bunga pinjaman gadai tersebut. Perusahaan Umum Pegadaian hanya menganti 125\% dari nilai taksir barang jaminan yang mengalami kerusakan/hilang, atau sesuai dengan ketentuan yang berlaku dari pihak pegadaian. Kemudian usaha yang dilakukan Perusahaan Umum Pegadaian untuk menyelamatkan barang gadai dari kejadian yang disebabkan karena force majeure yang antara lain namun tidak terbatas karena, bencana alam, perang, huru-hara. Nasabah diwajibkan untuk mengganti biaya yang dikeluarkan Perusahaan Umum Pegadaian untuk menyelamatkan barang gadai nasabah dari kejadian tersebut. Kekuatan hukum yang digunakan Perusahaan Umum Pegadaian ini terletak pada Pasal 1157 ayat (2) yang berbunyi, "Sebaliknya si berutang diwajibkan mengganti kepada si berpiutang segala biaya yang berguna dan perlu, yang telah dikeluarkan oleh pihak yang tersebut belakangan ini guna keselamatan barang gadainya.

Ketentuan tentang bentuk perjanjian juga kita liat dalam Pasal 1151 Kitab Undang-Undang Hukum Perdata yang berbunyi, "Persetujuan gadai dibuktikan dengan segala alat yang diperoleh bagi pembuktian persetujuan pokok".

Perjanjian gadai dapat dilakukan dengan perjanjian tertulis yang isinya dibuat oleh Perusahaan Umum Pegadaian secara sepihak dan ditanda tangani oleh pemberi gadai (nasabah) dengan penerima gadai (perusahaan umum pegadaian).

Adapun kutipan dari perjanjian gadai yang dilakukan antara pemberi gadai (nasabah) dan penerima gadai (perusahaan umum pegadaian) mengenai barang bergerak adalah :

1. Pegadaian memberikan kredit kepada nasabah yang di kuasakan dengan jaminan barang bergerak yang nilai taksiran sebagaimana tercantum pada halaman depan.

2. Nasabah dan atau dikuasakan menjamin bahwa barang yang dijaminkan merupakan milik yang sah dari nasabah atau dikuasai secara sah menurut hukum oleh nasabah dan karenanya nasabah mempunyai wewenang yang untuk menjadikannya jaminan utang kepada Pegadaian. Nasabah juga menjamin bahwa tidak ada 
orang atau pihak yang lain yang turut mempunyai hak atas jaminan tersebut, baik hak memiliki maupun hak menguasai.

3. Nasabah menjamin bahwa barang digadaikan kepada Pegadaian tidak sedang menjadi jaminan sesuatu hutang, tidak dalam sitaan, tidak dalam sengketa dengan pihak lain atau tidak berasal dari barang yang diperoleh secara tidak sah atau melawan hukum.

4. Barang jaminan sebagaimana diuraikan di halaman depan, bila barang jaminan rusak atau hilang akan diganti $125 \%$ dari nilai taksiran, setelah dikurangi uang pinjaman dari sewa modal. Pihak Pegadaian tidak menjamin apabila rusaknya barang akibat bencana alam, huru-hara dan perang.

5. Apabila terjadi perbedaan taksiran dan menyebabkan nilai barang jaminan tidak dapat menutup uang pinjaman dan sewa modal, paling lama 14 hari sejak pemberitahuan. Nasabah atau yang dikuasakan berkewajiban menyerahkan tambahan barang jaminan yang nilainya minimal sama dengan nilai pinjaman ditambah sewa modal maksimum.

6. Nasabah atau yang dikuasakan berkewajiban untuk membayar uang pinjaman ditambah sewa modal sebesar tarif sebagaimana yang tercantum di halaman depan dengan jangka waktu kredit 120 hari.

7. Nasabah atau yang di kuasakan dapat mengalihkan haknya untuk menebus, menerima, atau mengulang gadai barang jaminan kepada orang lain dengan mengisi dan membubuhkan tanda tangan pada kolom yang tersedia.

8. Pelunasan dapat dilakukan dengan cara melunasi seluruhnya, mengangsur dan atau mengulang gadai, mulai sejak tanggal kredit sampai dengan satu hari sebelum tanggal lelang. Apabila sampai dengan tanggal jatuh tempo tidak dilunasi/diangsur atau diulang gadai, maka barang jaminan akan dilelang pada tanggal yang ditetapkan. 
9. Hasil penjualan barang jaminan digunakan untuk menutup pinjaman di tambah sewa modal dan biaya lelang. Apabila terdapat uang kelebihan yang menjadi hak nasabah dengan jangka waktu pengambilan selama 1 tahun, uang kelebihan tidak diambil dalam jangka waktu 12 bulan, sejak tanggal lelang selebihnya menjadi hak Pegadaian.

10. Apabila penjualan lebih rendah dari uang pinjaman tambahan sewa modal ditambah biaya lelang, selisihnya tetap merupakan utang nasabah yang harus ditagih oleh Pegadaian dan harus di lunasi paling lambat 14 hari sejak tanggal pemberitahuan penerima.

11. Apabila terjadi permasalahan dikemudian hari akan diselesaikan secara musyawarah untuk mufakat. Jika ternyata perselisihan itu tidak dapat diselesaikan secara musyawarah untuk mufakat, maka akan diselesaikan melalui Pengadilan Negeri setempat.

\section{SIMPULAN}

Sesuai dengan motto dari pegadaian yaitu "Mengatasi Masalah Tanpa Masalah", pegadaian berusaha menawarkan sejumlah fasilitas-fasilitas pinjaman agar para nasabah Perusahaan Umum Pegadaian tidak berpaling dari lembaga tersebut dengan memberikan pergantian kerugian sebesar $125 \%$ dari nilai taksiran barang jaminan yang mengalami kerusakan/hilang yang disebabkan bukan karena Force Majeure (keadaan memaksa) dan membuat asuransi atas atas barang jaminan tersebut untuk mendapatkan kepastian hukum bagi nasabah Perusahaan Umum Pegadaian. Dengan adanya Perusahaan Umum Pegadaian diharapkan mampu turut meningkatkan kesejahteraan masyarakat terutama golongan menengah kebawah melalui peneyediaan dana atas dasar hukum gadai dan untuk menghindarkan masyarakat dari gadai gelap, praktek riba, dan pinjaman tidak wajar lainnya

\section{DAFTAR RUJUKAN}

AFIF, M. R., Turatmiyah, S., \& Zaidan, M. (2018). Implementasi Perjanjian Jaminan Gadai Di Kantor Pt Pegadaian (Persero) Cabang Kota Palembang. Sriwijaya University.

Fahlevhy, A. (2016). Tinjauan Yuridis Pelaksanaan Perjanjian Pinjam Meminjam Uang Dengan Jaminan Benda Bergerak Di Perum Pegadaian Kantor Wilayah Senen Ix. Universitas 
Pembangunan Nasional Veteran Jakarta.

Hapsari, R. S. (2016). Perlindungan Hukum terhadap Nasabah dalam Hal Terjadi Kerusakan atau Kehilangan Barang Jaminan di PT. Pegadaian (Persero) Kota Madiun. Jurnal Repertorium, III(2), 114-120.

Hasibuan, N. S. M. (2017). Tinjauan Hukum Terhadap Pernyataan Pailit oleh Pengadilan karena Tidak Dipenuhinya Kewajiban Debitur Terhadap Kreditur (Studi Putusan No. O7/Pdt. Sus-Pailit/2015/PN. Niaga Mdn). Universitas Medan Area.

Herawaty, H. (2008). Tinjauan Yuridis Atas Kesetaraan Dalam Perjanjian Kredit Perbankan.

Kitab Undang-undang Hukum Perdata.

PP No. 10 Tahun 1990 tentang Pengalihan Bentuk Perusahaan Jawatan (PERJAN) Pegadaian Menjadi Perusahaan Umum Pegadaian.

PP No. 103 Tahun 2000 tentang Perusahaan Umum (PERUM) Pegadaian.

Puspita, J., \& Djaroem, R. (2004). Perusahaan Umum (Perum) Pegadaian sebagai Sarana Pemberian Kredit. Lex Jurnalica, 1(3), 17938.

Rahayu, D. P., SH, M. H., \& Ke, S. (2020). Metode Penelitian Hukum. Yogyakarta: Thafa Media.

Undang-Undang Perlindungan Konsumen Nomor 8 Tahun 1999.
Usanti, T. P. (2019). PERLINDUNGAN HUKUM BAGI NASABAH PERUSAHAAN PERGADAIAN. Lex Journal: Kajian Hukum \& Keadilan, 3(1). 